Europe's Journal of Psychology, 7(2), pp. 204-217

www.ejop.org

\title{
Psychology, domination and resistance
}

\author{
By Stephen Reicher \\ University of St. Andrews
}

\section{Two sides of the human condition}

In my first year as an undergraduate two things drew me into psychology and made me passionate about the subject. Now, over 35 years later, they make me passionate still.

The first experience was hearing Henri Tajfel lecture. In these days of assessments and league tables we often measure a teacher by what is easiest to measure: the provision of good lecture handouts, clear course objectives and aims, clear feedback and so on. What Henri had was the capacity to inspire, the ability to make you care about the questions and therefore motivate you to find out the answers. The questions he asked - about group bias, about intergroup hatred, and above all, how can we explain (and perhaps help contain) real life atrocities - derived from his own past as a Polish Jew in the Second World War. And they touched on my past, for my family too are Jewish and my father came from Poland.

The second experience may seem mundane, even trivial, by comparison. But it marked me just as deeply. At about the same time as I was learning about group processes, the Student's Union voted to occupy the University administration buildings in support of a demand for nursery provision. Coming from a nice polite middle-class background I wasn't sure about occupations and I was a little scared of getting mixed up with those extremists so castigated in the media and whom my parents had warned me about. I was also afraid of how the University might respond (and indeed the University did try, unsuccessfully, to expel several of those involved). But in the end I felt that if I had participated in the debate and the vote, I had to accept the decision and so I spent the next few days and nights in Bristol University's Senate House. 
It was the most remarkable few days for me. I had never known so many people debate so seriously and so intensely about something that would give them no personal benefit. The issue may have been a nursery, but the cause was equal access to University for women. And we talked long into the night about how to publicise and spread and win our cause. There was an intellectual intensity I had hoped to find in everyday student discussions - but hadn't. There was a sense of principle which I had been led to believe in but generally seen honoured in the breach. There was a sense of warmth and generosity between people that I remember still. Yet, when others (such as the University Vice-Chancellor) spoke of us, it was in terms of a very old pathologising language of 'the mob'. We were, he said, the gullible led by the culpable: immature students carried away in the group and exploited by seasoned activists.

These two experiences, then, invoke the two sides of group psychology and underline the fact that groups create both the worst of worlds and the best of worlds. On the one hand, groups can dominate, denigrate, dehumanize and even destroy others. On the other hand, groups not only lead to bonds of care and solidarity internally, they also challenge and destroy systems of inequality between groups. Indeed, to borrow the old Trades Union slogan, the power of the powerless lies in their combination. Take away the ability to combine and hierarchy (or even tyranny) will always remain secure.

To make the same point slightly differently and more generally, psychology - social psychology in particular, group psychology especially - needs to address both domination and resistance, stasis and movement, social reproduction and social change. Any approach which emphasizes the one to the exclusion of the other will necessarily be deficient in its ability to explain both. It may be that, over long periods of time, our social worlds seem stable and set and that their inequalities are destined to last. But change - underpinned by collective action - is always possible and should warn us against eternalizing what is generally only a temporary lull. Perhaps right now, when seemingly strong states like Tunisia and Egypt have folded like a pack of cards and who knows how many others will follow in their wake, this point should be easier to make than at other times. But the same might have been said in 1789, 1830, 1848, 1871, 1917, 1968, 1989. Yet we seem to have short memories. This point at least tends regularly to be forgotten.

This is an argument I have developed with Alex Haslam, and what follows has arisen out of our joint discussions and our joint work. It is as much Alex's as my own. 
Naturalising inequality

The tendency to naturalise the social order, thereby to exclude social change and to make resistance futile, is as old as recorded social thought. Yet, in different ages, and under different social orders, the form of naturalization changes. We well remember Plato's division of humanity into men (and only men) of gold, men of silver, and men of bronze, each destined to fill different places in the social order. As Plato puts it (or at least, as Plato has Socrates explain to his pupil Adeimantus) only a tiny number of people are born with the intellectual and moral qualities to rule over the brutish mass (Plato, 380BC/1993). While vestiges of this sort of idea survive to this day (see, for instance, Leon Kamin's work on justifications of racial inequality and, in particular his magnificent 1993 essay with the irresistible title 'On the length of black penises and the depth of white racism') such blatant elitism is generally out of favour in today's more democratic times. We tend to favour explanations which assign certain characteristics to all human beings - characteristics which make us naturally suited to the world as it is and which reduce any alternative to a hopeless fantasy.

A combination of the (mis) use of evolutionary theorizing and the reductive use of powerful new technologies such as brain imaging has led to claims that everything from selfishness and exploitation to conflict and aggression are somehow inscribed into the human psyche (e.g. Buss, 2005; Dawkins, 1976; Pinker, 2002). However, if one natural difference between types of people survives, it has to do with gender. Men, it seems, are not only 'naturally' more aggressive and exploitative than women, it is natural for men to dominate, exploit, and even rape women (Thornhill \& Palmer, 2001).

In part, at least, the growing influence of such naturalizing accounts can be put down to the decline of large scale social psychological studies of human behavior. Gradually, as the great field studies of the post-war period produced more and more spectacular evidence of the ways in which context could affect behavior, they raised more and more acute ethical issues about the acceptability of manipulating our social worlds. Already, in his 'boys camp studies', Muzafer Sherif had shown how you can take well-adjusted and decent young boys and turn them to violence and aggression. The Sherifs (Muzafer and his wife Carolyn) famously issued "a warning to psychologists to consider fully the importance of the background and the context of behavior in a social situation" (Sherif \& Sherif, 1969, p. 252). They continued: "If an outside observer had entered the situation after the conflict began... he could only have concluded on the basis of their behaviour that 
these boys (who were the 'cream of the crop' in their communities) were either disturbed, vicious or wicked youngsters". (1969, p. 254).

In 1961 (we celebrate the half-centenary this year) Stanley Milgram went on to show how contextual manipulations could have as much impact on adults as on children and could lead ordinary Americans to deliver what they believed to be lethal electric shocks to another in a mock learning experiment. In 1971, Philip Zimbardo went even further and turned Californian students into either sadistic guards or else disturbed prisoners in his Stanford Prison Experiment (SPE).

Enough was enough. Zimbardo's prison was so toxic that the two week study had to be halted after only six days. But more seriously, for the ensuing 40 years, it has been all but impossible to run such powerful studies again (though see Reicher \& Haslam, 2006 and www.bbcprisonstudy.org). Indeed, over time, we have not only retreated almost entirely into the laboratory, we have even eliminated interaction from the studies we conduct there (Haslam, \& McGarty, 2001). The problem, then, if we cannot set up new and immersive social worlds in order to see how they impact upon people, is that other asocial explanations will prevail. It may be that anyone who sees just how dramatically someone can be turned from passivity to aggressivity by the circumstances they find themselves in (that is, someone who has access to the type of history whereby Sherif's youngsters were transformed from 'the cream of the crop' to vicious antagonist) will never again be satisfied with static explanations of the phenomena. However, if we cannot see, or if that history is denied to us, then our explanations will likewise become skewed towards stasis.

\section{Conformity bias in classic social psychology}

But I am being too kind to my own. The problem isn't only that social psychology has been usurped from the outside. It also lies within social psychology itself. For, while the great field studies may have demonstrated the power of context, and hence shown how altered contexts lead to altered behaviours, they also went further (or, at least, they have generally been interpreted as going further). They have been used to argue that context is so powerful that it obliterates the individual, that people cannot resist the circumstances in which they find themselves and that they can only conform.

Empirically, then, these studies impose particular contextual conditions upon participants. They don't address how people create or transform contexts for themselves - and even when they do (so, for instance, in Sherif's 1954 'Robber's 
Cave boys camp study, the boys wanted to create competition as soon as they learnt of the existence of another group and before competitions were organized by the experimenters) this is generally ignored in the analysis. Thus context becomes something external to participants which contains and constrain show they (inter)act. It is not something that emerges out of these interactions themselves.

This neglect is underpinned by theoretical approaches which, either by omission or by commission, deny agency to people especially in collective contexts. Thus, either a straight line is drawn from context to action as if people will always behave in set ways within a given context or else it is claimed that when people are engaged with others, they lose their capacity for critical judgment, they become thoughtless and they simply go along with whatever is suggested to them. This latter approach is common both to Milgram's 'agentic state' account of the obedience studies (Milgram, 1974) and Zimbardo's role account of the Stanford Prison Experiment (Zimbardo, 2008). The difference is that, in Milgram's account, these suggestions require a leader to be present whereas in Zimbardo's account they are generated by the role itself without anyone being needed to spell out how one should act.

As Moscovici (1976) noted, the conceptual problem with such a monolithic 'conformity bias' approach is that it leaves us with a one-sided social and group psychology. It invokes the power of the group context while at the same time pathologising group psychology. It stresses the power of immersion in groups to make people behave in toxic ways but it doesn't stress the power of the group to challenge toxic situations. It dramatizes domination but it downplays resistance. And to realize that all this is a problem, one doesn't have to make claims about the nature of the wider society. One can simply look at these classic studies themselves. For even if it is ignored in practice and denied in theory, all of them are dripping with resistance!

In the boys camp studies, for instance, the attempts to divide groups of boys and set them up in competition against each other was not always successful. The second study, in 1953, resulted in the two groups getting together and refusing to believe that the other was their antagonist. This study was abandoned and never fully written up. As so often, those who challenge the reality of the experimenter are not used to study how people make their own history. Rather they are written out of (the official scientific) history.

In Milgram's studies, the rate of obedience varied from $0 \%$ to $100 \%$. So in effect they are studies of disobedience as much as obedience and the question needs to be 
less 'why do people obey' than 'when do people obey'. These rather obvious points are somewhat obscured by the fact that, even if not entirely obliterated, the focus has been somewhat removed from the disobedient cases. In part this comes from reducing the complexity of the results by focusing on one version (dubbed the 'standard' version for no particularly good reason; Russell, 2011) which tends to be cited in textbook accounts and in which the clear majority of people do comply (Reicher \& Haslam, 2011). In part it comes from Milgram's skills as a film maker and the fact that he only made available film of the compliant trials (Millard, 2010). These pictures, by now old and flickering, literally dominate the field. They perpetuate a misleading image of monolithic conformity. They stop us asking us about the 'when' and lead us back to asking only why people obey.

And when it comes to the Stanford Prison Experiment, it is hard to know where to start with tales of resistance. The prisoners resisted their roles from the start. At the end of the first day they were united and dominated the Guards. Until the very end, some prisoners continued to resist even if they had now become isolated. The Guards also resisted their roles. As Zimbardo himself acknowledges, some actively helped the prisoners, some were firm but fair, only a few were actively malicious. Indeed the evidence of mistreatment relates almost exclusively to one individual dubbed 'John Wayne' for his aggressive swagger (Zimbardo, 1989). So, once more, a balanced account needs certainly to ask about domination. But it also needs to ask about resistance. Above all, it needs to ask what determines which predominates and which prevails; Haslam \& Reicher, 2006, 2010).

\section{Conformity bias in contemporary social psychology}

These classics, of course, are now (as the term itself suggests) part of our history. Even if there has been little challenge to the conceptual account of the studies themselves, in the discipline as a whole such notions as agentic state or role immersion hold little sway. But I use these less for their own importance as exemplars of 'conformity bias' approaches. And, if anything, such approaches have gained increasing sway in recent years. Take, for instance, the recent rise of system justification theory (e.g. Jost, Banaji \& Nosek, 2004). The notion of system justification is originally taken from Henri Tajfel's work (Tajfel, 1981). In Tajfel's hands, this is but one of several functions of social stereotypes. Moreover, his interest (and the focus of his social identity theory) lies precisely in the structural and ideological dynamics which determine precisely when members of subordinated groups will accept an unequal status quo and when they will begin to challenge it (Tajfel \& Turner, 1979). However, once the notion of system justification is inflated into a theory, all balance is lost and 
a construct which was meant to help us understand dynamic social processes is used to impede an understanding of such dynamics. The argument becomes lopsided again. The claim is that people have inherent tendencies to buy into their own oppression and that we cannot help but bolster the status quo. Sad, perhaps, but that is the way we are built (see Reicher, 2004).

Similar points can be made about social dominance theory (Sidanius \& Pratto, 1999), another approach which has gained great traction over the last decade or so. Again, there is nothing problematic about the concept of social dominance in itself. Moreover, there is much that is constructive and attractive in the work of Sidanius, Pratto and others: to start with, they put issues of power and inequality back at the core of social psychology, they point to the role of institutions and states in buttressing inequality, they demonstrate the impact of hierarchical beliefs (Sidanius, van Laar, Levin \& Sinclair, 2003). But the problem lies in the fact that, in social dominance theory, social dominance (like system justification in system justification theory) is not seen as an ideology, which is articulated by particular groups at particular times and discarded at others (cf. Schmitt, Branscombe \& Kappen, 2003). That is, it is not seen as a variable which is to be explained in terms of social processes. It is seen as a constant which serves to exclude social variation. To be less cryptic, social dominance is seen as a stable individual difference, but also a stable group difference (e.g. men are higher in social dominance than women - the 'iron law of andrancy' as they term it) which is underpinned by evolution. Thus the theory openly claims that hierarchy, dominance and inequality are an inevitable aspect of the human condition (see, for instance the title of a 1993 chapter by Sidanius \& Pratto: "The inevitability of oppression and the dynamics of social dominance"). In this way social dominance provides yet another analysis in that long line going back to Plato and beyond which tells us that resistance is futile.

As I write this, I am reading at home the autobiography of an Indian Dalit ('Untouchable') woman Baby Kamble, who grew up in the early part of the twentieth century (Kamble, 2008). Her book is really more of a sociobiography. It tells of the condition and the fate of one of the most oppressed groups on earth. It tells how the untouchables, the women in particular, were seen and treated as subhuman. They ate the slops of the higher castes who considered even the sound of their voice as polluting. It also tells how they accepted their position and embraced the Hindu religion which rejected them. But it also tells of change, of how 'untouchable' became politicized as Dalit. It relates how people joined the movement led by Dr. Ambedkar (a far greater figure than Gandhi to these people), how they refused to serve the higher castes in the villages and how they converted 
en masse to Buddhism. The book is a cry of rage against a system and a religion which lays people low. But even more it is a cry against those 'untouchables' who still try to assimilate to this system and still accept an ideology of hierarchy.

Kamble's book is entitled 'The Prisons We Broke'. The language is echoed in John Turner's trenchant critique of conservative psychological theory. His immediate target was Zimbardo's role account of the Stanford Prison Study (Turner, 2006), but it applies more generally to the various models I have outlined above. Turner argues against theories which imprison us in the present by denying our ability to challenge authority and alter inequality. He calls for us to break our theoretical prisons just as Kamble calls on Dalits to break their ideological prisons. Moreover, the two are linked insofar as psychological theory can (and often has) become a key part of the ideology which seeks to keep people in their place whether by justifying inequality through the attribution of different qualities to different groups of people (Gould, 1983; Kamin, 1977) or else (as I have stressed here) by ruling out any alternatives to the existing social order (Tajfel, 1978).

In 'escaping our theoretical prisons' (as Turner advocates), we don't just gain a deeper understanding of how change can occur, we also gain an understanding of how the status quo is maintained. Indeed, the irony is that, by making social reproduction natural and inevitable, we lose sight of all the work at different levels including the psychological - which goes into ensuring that social systems endure over time. How is it that certain groups legitimate their privileged position? How do they stop subordinate groups coming together to challenge them? In a contemporary world where bankers continue to get bonuses while others (including those of us in the academic sector) lose jobs and services because of the crisis that the bankers caused, these are pertinent questions for us all. To quote the Governor of the Bank of England, Mervyn King, why is the public not angrier than it is? (quoted in 'Should we be more angry about the causes of the financial crisis?' The Guardian, March $2^{\text {nd }} 2011$ )? In order to answer this question we need what we plainly do not have: a social psychological analysis of the processes of domination.

Viewed in this way, it is clear that the analysis of resistance and the analysis of domination are not separate orders of enquiry. Rather they are two sides of the same coin - or rather, they constitute different outcomes from the same process. Domination results from the successful demobilization of challenges to the status quo whereas resistance results from successful mobilization. Moreover, demobilization is achieved by getting people to adopt a common categorization with those who are dominant, or at least by stopping seeing themselves and acting as a distinct group with antagonistic interests (see Haslam \& Reicher, 2011). Mobilization is achieved 
precisely by creating a sense of autonomous selfhood amongst the subordinated in society - what in Marxist terms would be termed the group (specifically, class) for itself (für sich; Marx \& Engels, 1848/2002).

\section{Domination and resistance in the Holocaust}

I started off by referring back to two formative experiences in my time as a psychologist - the Holocaust as a site of domination, an occupation as a site of resistance. But as time goes by, I become increasingly aware that as long as we separate out these issues and associate them with different phenomena, we miss the point. The point is that the same phenomena encapsulate both issues. One might well ask how can one study resistance as well as domination in the Holocaust? After all, the received wisdom is that the Holocaust was possible because people largely went like sheep to the slaughter, and if we occasionally focus on exceptions such as the Warsaw Ghetto uprising of 1943, that is precisely because they are exceptions (Mais, 2007-8).

But in recent years, this viewpoint has been challenged on several fronts. To start with, Warsaw was far from unique. There were armed undergrounds in more than 90 ghettos (Gurewitsch, 2007-8) and there were armed uprisings in three of the six Nazi extermination camps: Auschwitz, Treblinka and Sobibor (Arad, 1987; Suhl, 1975; Venezia, 2007). What is more, resistance didn't only take the form of uprisings (in which a few of the fighters might conceivably survive, but the weaker members of the the ghetto would inevitably be killed). It took other forms such as escape and joining the partisans (Epstein, 2008; Marrus, 1995). More radically still, it has been argued that even those in the Jewish Councils who ran the ghettos cannot be assumed to be passive and collaborationist. Rather their stance was rooted in a historical experience of oppression and of successfully surviving that oppression by hunkering down, maintaining communal organization and seeking to outlive the oppressor - a strategy known as iberleben (Engel, 2007-8). Clearly this strategy failed, because Nazi exterminationism was something radically new. But it is only in hindsight that we know this. At the time how could anyone believe that the Nazis would do something so extreme, so unprecedented and so ridiculous to people who were working hard in ghetto factories for their war effort? (Horwitz, 2010).

In effect, then, everyone sought to resist the Germans but used more of less confrontational strategies as a function of how they understood the nature of their oppressor (Einwohner, 2009; Tiedens, 1997). So if it is true that Jews were led to be slaughtered, they did not generally go as sheep. Moreover, it would be dismissive to 
say that the resistance failed because most resistors died. Once they became aware of their fate, people sought to act in ways that would maintain Jewish dignity and empower Jewish people in the future. Whatever one's stance on the State of Israel, one should not underestimate the impact of Holocaust resistors on the success of subsequent struggles.

I have just one more point to make about the Holocaust. It was precisely because they were aware of the potential for (and the reality of) resistance, that the Nazis went to such lengths to fragment Jewish solidarity. In the ghettos they went through countless elaborate charades to convince those left behind that deportations meant transfer to a better life rather than to certain death, a deception that they maintained even as people entered the camps and symbolized by the infamous sign over the gates to Auschwitz: 'Arbeit Macht Frei' (Gutman, 1971; Horwitz, 2010).

Once people were in the camps and the slaughter could no longer be hidden, other means were used to isolate people from the others whom were tightly packed together. Indeed the whole camp system was specifically design to stop people developing bonds of common identity and solidarity - the use of divide and rule, the system of preferments and privileges, the systematic use of humiliation and many other techniques besides (Sofsky, 1997; see also Haslam \& Reicher, 2011). Passivity did not come naturally, it was actively produced.

The Holocaust, then, is a site of domination and resistance. We cannot understand it without studying both. Nor can we understand either element without understanding the other. Unless we know what makes resistance effective we cannot tell what disrupts opposition and maintains the status quo. Unless we know what serves to maintain the status quo we cannot know what needs to be disrupted for resistance to flourish.

As social psychologists, then, we must not counter the present unbalanced emphasis on domination by an equally unbalanced turn to resistance. We must study the two together. That is a major challenge. It is the challenge that brought me into psychology. It is the challenge which maintains my passion for our discipline. It is a challenge that will keep me busy for many years to come.

\section{References}

Arad, Y. (1987) Belzec, Sobibor, Treblinka: The Operation Reinhard death camps. Bloomington: Indiana University Press. 
Buss, D.M. (2005) The Murderer Next Door. London: Penguin.

Dawkins, R. (1976) The Selfish Gene. Oxford: Oxford University Press.

Einwohner, R.L. (2009) The need to know: Cultured ignorance and Jewish resistance in the Ghettos of Warsaw, Vilna and Lodz. Sociological Quarterly, 60, 407-430.

Engel. D. (2007-8) Resisting in Jewish time. In Y. Mais (ed.) Daring to Resist: Jewish defiance in the Holocaust. New York: Museum of Jewish Heritage.

Epstein, B. (2008) The Minsk Ghetto 1941-43: Jewish resistance and soviet internationalism. Berkeley: University of California Press.

Gould, S.J. (1983) The Mismeasure of Man. New York: Norton.

Gurewitsch, B. (2007-8) To get killed or to kill. In Y. Mais (ed.) Daring to Resist: Jewish defiance in the Holocaust. New York: Museum of Jewish Heritage.

Gutman, I. (1971) Youth movements in the Underground and the Ghetto revolts. In Yad Vashem Jewish Resistance During the Holocaust: Proceedings of the conference on manifestations of Jewish Resistance. Jerusalem: Yad Vashem.

Haslam, S.A. \& McGarty, C. (2001) A 100 years of certitude? Social psychology, the experimental method and the management of scientific uncertainty. British Journal of Social Psychology, 40, 1-21.

Haslam, S. A., \& Reicher, S. D. (2006). Stressing the group: Social identity and the unfolding dynamics of responses to stress. Journal of Applied Psychology, 91, 1037-1052.

Haslam, S. A., \& Reicher, S. D. (2010). Beyond conformity: Revisiting classic studies and exploring the dynamics of resistance. In J. Jetten \& M. J. Hornsey (Eds.). Rebels in groups: Dissent, deviance, difference and defiance (pp.324-344). Chichester, UK: WileyBlackwell.

Haslam, S. A., \& Reicher, S. D. (2011). When prisoners take over the prison: A social psychology of resistance. Unpublished manuscript: Universities of Exeter and St. Andrews.

Jost, J.T., Banaji, M.R. \& Nosek, B.A. (2004). A decade of system justification theory: accumulated evidence of conscious and unconscious bolstering of the status quo. Political Psychology, 26, 881-919. 
Kamble, B. (2008) The Prisons We Broke. Delhi: Orient Longman.

Kamin, L. (1977) The Science and Politics of IQ. Harmondsworth: Penguin.

Kamin, L. (1993) On the length of black penises and the depth of white racism. In L.J. Nicholas (Ed.) Psychology and Oppression. Skotaville Publishers: Johannesberg.

Mais, Y. (2007-8) Daring to Resist: Jewish Defiance in the Holocaust. New York: Museum of Jewish Heritage.

Marrus, M.R. (1995) Jewish resistance in the Holocaust. Journal of Contemporary History, 30, 83-110.

Marx, K. \& Engels, F. (1848/2002) The Communist Manifesto. London: Penguin.

Milgram, S. (1974) Obedience to Authority. London: Harper Collins.

Millard, K. (2010). Stanley Milgram's story machine: Experimental psychology, improvisation and the reinvention of the screenplay. Paper presented at "Screenwriting: History, Theory, Praxis" conference. Copenhagen, 9-11 September

Pinker, S. (2002) The Blank Slate. London: Penguin.

Plato (380BC/1993) The Republic. Oxford: Oxford University Press.

Reicher, S.D. (2004) The context of social identity: Domination, resistance and change. Political Psychology, 25, 921-946.

Reicher, S.D. \& Haslam, S.A. (2006) Rethinking the psychology of tyranny: the BBC Prison study. British Journal of Social Psychology, 45, 1-40.

Reicher, S.D. \& Haslam, S.A. (2011) After shock? Towards a social identity explanation of the Milgram 'obedience' studies. British Journal of social Psychology, 50, 163-169.

Russell, N. (2011) Milgram's obedience to authority experiments: orogins and early evolution. British Journal of Social Psychology, 50, 140-162

Scmitt, M.T., Branscombe, N.R. \& Kappen, D.M. (2003) Attitudes towards group based inequality: social dominance or social identity? British Journal of Social Psychology, 42, 161-186. 
Sherif, M. \& Sherif, C.W. (1969) Social Psychology. New York: Harper \& Row.

Sidanius, J., van Laar, C., Levin, S \& Sinclair, S. (2003) Social hierarchy maintenance and assortment into social roles: a social dominance perspective. Group Processes and Intergroup Relations, 6, 333-352.

Sidanius, J. \& Pratto, F. (1993) The inevitability of oppression and the dynamics of social dominance. In P.M. Sniderman, P.E. Tetlock \& E.G. Carmines (Eds.) Prejudice, Politics and the American Dilemma. Stanford: Stanford University Press.

Sidanius, J. \& Pratto, F. (1999) Social Dominance. Cambridge: Cambridge University Press.

Sofsky,W. (1997). The order of terror: The concentration camp. Princeton, NJ: Princeton University Press.

Suhl, Y. (1975) They fought back: The story of Jewish resistance in Nazi Europe. New York: Shocken Books.

Tajfel, H. (1978) Differentiation Between Social Groups. London: Academic Press.

Tajfel, H. (1981) Social stereotypes and social groups. In J.C. Turner \& H. Giles. Intergroup Behaviour. Oxford: Blackwell.

Tajfel, H. \& Turner, J. C. (1979). An integrative theory of intergroup conflict. In W. G. Austin \& S. Worchel (Eds.), The social psychology of intergroup relations (pp.33-47). Monterey, CA: Brooks/Cole.

Thornhill, R. \& Palmer, C.T. (2001) A Natural History of Rape. Boston, Ma: MIT Press.

Tiedens, L.Z. (1997) Optimism and revolt of the oppressed: A comparison of two Polish Jewish Ghettos of World War II. Political Psychology, 18, 45-69.

Turner, J.C. (2006) Tyranny, freedom and social structure: escaping our theoretical prisons. British Journal of Social Psychology, 45, 41-46.

Venezia, S. (2007) Sonderkommando: Dans l'enfer des chambers a gaz. Paris: Albin Michel.

Zimbardo, P. (1989). Quiet rage: The Stanford Prison Study video. Stanford CA: Stanford University.

Zimbardo, P. (2008) The Lucifer Effect. London: Rider. 
About the author:

Stephen Reicher is currently Professor of Psychology at the University of St. Andrews. $\mathrm{He}$ is a Fellow of the Royal Society of Edinburgh, an Academician of the Social Sciences, Scientific Consultant to Scientific American Mind and a past Editor of the British Journal of Social Psychology. Stephen's work concerns the relationship between social identity and collective action. Within this framework, he has studied such phenomena as crowd behaviour, intergroup hatred, leadership and mobilisation, national identification, and the psychology of tyranny. He has getting on for 200 publications in these and other areas. His latest book, with Alex Haslam and Michael Platow is The New Psychology of Leadership (Psychology Press 2010).

Address for correspondence: Stephen Reicher, School of Psychology, University of St. Andrews, St. Andrews, Fife, KY16 9JU.

Email: sdr@st-andrews.ac.uk 